\title{
Working capital management policies and value creation of listed non-financial firms in Ghana: A panel FMOLS analysis
}

\author{
Siaw Frimpong \\ School of Business, University of Cape Coast, Cape Coast, Ghana \\ corresponding e-mail: Sfrimpong[at]ucc(dot)edu\{d\}gh \\ address: Department of Finance, School of Business, University of Cape Coast, Cape Coast, Ghana
}

\begin{abstract}
The aim of the study was to determine effects aggressive/ conservative working capital policies have on the value creation. Data from 10 listed non-financial companies on the Ghana Stock Exchange spanning from 2004-2015 was used for this study. The study adopted quantitative research design applied to panel cointegration technique and panel fully modified ordinary least square methodology. The panel cointegration results indicated that there was a long-run equilibrium association between working capital variables and shareholders' value creation. The panel FMOLS results indicated that aggressive current asset investment policies enhance market-to-book ratio in the long-run. On the other hand, conservative current asset financing policies enhance market-to-book ratio in the long-run.

This study has two contributions. First, prior studies investigated the connection existing between components of working capital management and shareholder value creation without investigating the specific policies these firms are pursuing and their effect on the shareholders' value creation. Second, this study employs a contemporary econometric methodology in analyzing the data.
\end{abstract}

JEL Classifications: G31, C23

Keywords: Aggressive current asset investment policies, conservative current asset financing policies, cointegration, panel fully modified, market-to-book ratio

Citation: Frimpong, S. (2018). Working capital management policies and value creation of listed nonfinancial firms in Ghana: A panel FMOLS analysis. Business and Economic Horizons, 14(4), 725-742.

http://dx.doi.org/10.15208/beh.2018.51

\section{Introduction}

Working capital management in recent times has been identified as a key driver for shareholder value creation. Following Rappaport's seminal paper on shareholder value over the past two decades, attention has now been focused on corporate managers to create a sustainable shareholder value by taking decisions that will maximize the firms' value. Shareholder value is now seen as an important performance indicator for companies (Gross, 2006) and that its enhancement has become the key responsibility of corporate executives and finance managers (Narang \& Kaur, 2014). Corporate financial decisions are normally classified as long term and short term. The notion is that only long term financial decisions impact the firm value in the long run whereas short term decisions have short term implications on the firm value. Adam, Quansah, \& Kawor (2017) posit that decisions involving working capital management concentrate on current assets and liabilities, their implications on firm profitability and shareholder value go beyond short term. Similarly, as argued by Watson \& Head (2007) companies can only reap the expected benefit from long term investment and financing decisions if they also effectively manage their short-term asset and liabilities. 
The management of working capital has become a major issue following the 2007-2009 financial meltdown that hit the world economy. A research conducted by CFO magazine in 2010 to find out how the financial crises had affected business in relation to the management of their short term assets and liabilities revealed that effective management of working capital was taken place among the European companies as short-term credit remained both difficult to access and costly. Additionally, Ernst \& Young's working capital management report (2016) revealed that most US and European companies were tying up working capital, in excess of the level required in order to conduct their businesses effectively and efficiently.

In an emerging economy like Ghana, efficient management of working capital cannot be over-emphasized. Majority of listed firms in Ghana have exhibited dwindling returns as well as poor stock performance in the last few years. On September 6, 2013, African Champion Industries Ltd, one of the listed manufacturing companies in Ghana closed down its manufacturing line as a result of persistent losses the company has been battling with over the years and consequently disposed of its assets (2013 company's annual report). According to Deloof (2003), the manner through which a firm manages its working capital may impact significantly on its profitability and consequently its value. Can this development be attributed to the way in which working capital is being managed? There are scant empirical studies which had been undertaken involving of working capital policies and shareholder value creation albeit its importance.

Working capital investment is identified as one of the factors for creating shareholder value among other factors such as fixed capital investments, costs of capital, income tax rate, sales growth rates, operating profit margin, and period of competitive advantage (Black, Wright, Bachman, \& Davies, 1998; Rappaport, 1986). These factors are considered as the building blocks of shareholder value creation (Kumar, 2015). Even though, a lot of research scholars and practitioners have argued that efficient working capital management increases profitability and an enhancement in firm's value and consequently shareholder value creation (Bammeri \& Dehani, 2013; Deloof, 2003; Kieschnick et al., 2013; Oseifuah \& Gyekye, 2017; Shin \& Shoenen, 1998; Smith, 1980; Wasiuzzaman, 2015), not much empirical work have been undertaken in this regard. According to Baños-Caballero, García-Teruel, \& Martínez-Solano (2014), it is generally accepted that working capital management affects firm's value, there are scarce empirical evidence on the valuation effects of investment in working capital. Additionally, prior studies investigated the association between the components of working capital and shareholder value creation. However these empirical studies did not consider the specific policies the firms were following and their effect on the shareholders' value creation (Bammeri \& Dehani, 2013; Duggal \& Budden, 2015; Oseifuah \& Gyekye, 2017; Wasiuzzaman, 2015). Furthermore, available empirical evidence suggests that earlier studies on the subject employed static Ordinary Least Squares (OLS) regressions without checking for stationarity or cointegration in their data series (see for example, Bammeri \& Dehani, 2013; Duggal \& Budden, 2015; Oseifuah \& Gyekye, 2017; Afza \& Nazir, 2009; Agyemang \& Asiedu, 2013; Akoto, Awunyo-Vitor, \& Angmor 2013; Korankye \& Adarquah, 2013; Al-Shubiri, 2011; Deloof, 2003; Eljelly, 2004; Mohamad \& Saad, 2010; Shin \& Soenen, 1998, etc.). This study therefore seeks to fill this gap by employing a recently developed econometric methodology in order to correct some of these methodological flaws using listed nonfinancial firms listed on the Ghana Stock Exchange.

The following objectives guided the study: 
- Establish whether long-run association exists among working capital policies and value creation of the non-financial firms listed on the Ghana Stock Exchange.

- Determine the effect of aggressive/ conservative current asset investment policy on value creation of the non-financial firms listed on the Ghana Stock Exchange.

- Determine the effect of aggressive/conservative current assets financing policy on value creation of the non-financial firms listed on the Ghana Stock Exchange.

\section{Research hypotheses}

$\mathbf{H 0}_{1}$ : there is no significant long-run association among current assets investment and financing policies and value creation of listed non-financial companies on GSE.

$\mathbf{H 0}_{2}$ : there is no significant effect of aggressive/conservative current assets investment policy on value creation of listed non-financial companies on GSE.

$\mathbf{H 0}_{3}$ : there is no significant effect of aggressive/conservative current assets financing policy on value creation of listed non-financial companies on GSE.

The rest of the paper is organised as follows: Section three reviews the empirical literature whiles section four discusses the research methodology. Sections five and six present the results of the study and conclusion respectively.

\section{Literature review}

\subsection{Working capital management and cointegration}

Prior studies mostly done on this subject tested the association between working capital management variables and firms' performance indicators. However, cointegrating relationships in the area of working capital management, profitability and liquidity have recently begun to gain the attention of scholars. The researcher found very little studies which provided empirical evidence in relation to cointegrating relationship.

Akinlo (2011) undertook a study to ascertain the long-run relationships and causality which existed between working capital and profitability using a sample of 66 firms in Nigeria for the period 1999-2007. In order to ensure stationarity of the variables the study applied three panel unit root tests, namely LLC, IPS, and Hadri tests. Using Pedroni (1999) panel residual based cointegration approach to find out the long-run relationship, the study indicated that there was a long-run equilibrium association between working capital and profitability.

In another study, Awad \& Jayyar (2013) studied the directional effect of working capital management and liquidity on profitability. Using gross operating profit as a measure of profitability and cash conversion cycle as a measure of working capital management with size, debt ratio and financial ratio as a control variables, their cointegration results based on Kao (1999) show that profitability, working capital management, firm size and debt ratio have a common trend in the long run. Their findings also indicated that there was a bi-directional causal relationship existing between working capital management and profitability. 
More recently, Adam et al. (2017) in their study found long-run association between working capital management policies and firms return proxy by return on equity.

\subsection{Working Capital Management and value creation}

Several empirical investigations have been conducted to unravel the relationship existing between firms' profitability and working capital management. Notwithstanding, little attention has been given to the area of working capital policies and value creation. Evidence from these studies is varied. Whereas Oseifuah \& Gyekye 2017 found that inventory conversion period and receivable conversion as well as account payable deferral period all have significant positive effect on firm value measured as market capitalization, Bammeri \& Dehani (2013) found no significant effect of inventory conversion period, account receivable collection period and account payable payment period on shareholder value creation proxy by stock returns at the conventional level of significance. However, the study by Wasiuzzaman, (2015) reveals that improving the efficiencyin working capital by way of reducing investment in working capital yields in higher firm value. The study also finds that working capital efficiency significantly enhances firm value for financially constrianed companies.

The study by Nasir \& Afza (2009) sought to investigate the effect of working capital investment and financing policies on firm value measured as Tobin's Q and revealed that finance managers would increase value when conservative current assets investment and financing policies are followed. Mohamad \& Saad (2010) also studied working capital management and its effect on the performance of listed firms in Malaysia and concluded that there are significant negative relationships among working capital management variables (TCL/TA and CCC) and Tobin's Q, whilst TCA/TA ratio shows a positive significant relationship with Tobin's Q.

The study by Al-Shubiri (2011) also revealed that aggressive financing policy is positively associated with Tobin's Q) whereas aggressive investment policy was negatively correlated with Tobin's Q. Additionally, Ankudinov \& Lebedev (2014) empirically examined how investing in a couple of assets may impact on shareholder value creation using data spanning the period 2004 to 2012 from the nonfinancial sector in Russia. The study discovered that firms which are investing excessively in working capital reduced value as investors trade with discount. However no statistical and significant effect was observed concerning company and investment in short-term financial assets..

Duggal \& Budden (2015) investigated the relationship between returns to shareholders and working capital investment by using a sample of 363 non-financial firms grouped under nine industrial sectors and belonging to S \& P 500 firms for the period 2009-2012. To estimate risk-adjusted shareholder returns the authors used the Treynor index. The main independent variable for their study was Net working capital estimated by current assets less current liabilities. The authors also used inventory, accounts receivable, cash and note payable deflated by the sales revenue as additional independent variables in their regressions in order to discover how these variables affect shareholder wealth. The result showed an inverse relation between net working capital and risk-adjusted shareholder returns. Additionally, whereas shareholder wealth is reduced by cash holdings, vendor financing and investing in inventory are able to enhance shareholder value. However, shareholder returns are not significantly affected by accounts receivable investments. 
Finally, Bandara (2015) examined the effect working capital management policies have on the value of firms. The sample for the study was taken from 74 firms belonging to Colombo Stock Exchange in Sri Lanka from 2009/10 to 2013/14. The dependent variable was market value added as whereas the explanatory variables were working capital investing policy and working capital financing policy. The panel regression results indicated an inverse relation between working capital investing policy and MVA. However, relationship between WCFP and MVA was found to be not statistically significant at the conventional level albeit the negative relationship. Based on this evidence, the author concluded Sri Lankan firms would generate higher MVA when the level of current asset investment is minimized.

\section{Research methods}

This study adopted a quantitative research design applied in panel cointegration framework to analyze the relationship between working capital policies and value creation of non-financial firms on the bourse of Ghana Stock Exchange.

\subsection{Population}

The population consisted of all the nonfinancial firms which were on the bourse of Ghana Stock Exchange on or before the year 2004 and were actively trading on the bourse as of $31^{\text {st }}$ December, 2015 with no recording of negative equity in their statement of financial positions during the study period. Also, firms which have their presentation currency other than Ghana Cedi were excluded. Finally firms with no available data were also eliminated. Based on this, the target population was made up of ten non-financial firms on the main Exchange. Appendix A provides the list of firms included in the sample.

\subsection{Data collection procedures}

The data for the study variables were obtained from annual reports and financial statements published by the firms from 2004 to 2015.These data were mainly obtained from the GSE factbooks and annual report Ghana database for the period of reference.

\subsection{Brief description of the study variables}

\section{Dependent variable}

Market-to-Book Ratio. According to Pandey (2005), shareholder value creation can be measured by comparing the market value per share and book value per share. A ratio higher than one means that value is created. However, a ratio less than one means that value is destroyed. Market-to-Book ratio (MBR) is calculated by the following formula:

$$
\frac{M}{B}=\frac{\text { Market Value of Equity }}{\text { Book Value of Equity }}
$$


Where, the market value of the equity is obtained by multiplying the number of shares in issue by the closing share price.

\section{Independent variables}

This study used aggressive/conservative current assets investment policy as well as aggressive/ conservative current asset financing policy (Weinraub \& Visscher, 1998; Nazir \& Afza, 2009) as measuring variables of working capital management policies. In order to measure current assets investment policy, the ratio below was formulated:

$$
T C A / T A=\frac{\text { Total Current Asset }}{\text { Total Assets }}
$$

Where a ratio less than 0.5 means a relatively aggressive investment policy whereas a ratio more than 0.5 indicates relatively conservative investment policy. On the other hand, to measure the aggressive/conservative financing policy the ratio below was also formulated:

$$
T C L / T A=\frac{\text { Total Current Liabilities }}{\text { Total Asset }}
$$

Where a ratio less than 0.5 means a relatively conservative financing policy whereas a ratio more tha 0.5 indicates relatively aggressive financing policy.

\section{Control variables}

Previous studies used control variables along with the main variables of interest in order to avoid estimation biases (see for example Atiyet, 2012; Naccur \& Goaied, 1999; Pandey, 2005). The study considered three control variables.

Financial Leverage. Atiyet (2012) argues that debts are means through which managers are disciplined by financial market, which is to reduce the agency cost of the shareholder's equity and thus increases the firms' return and value. Thus, the presence of debt enables managers to create more wealth for their shareholders. Following Pandey (2005) financial leverage is calculated as

$$
L E V=\frac{\text { Total Debt }}{\text { Total Capital }}
$$

Size. Various proxies are used for measuring size in empirical studies such as natural logarithms of total asset, total revenue, market capitalization and number of employees 
etc. (Jiang, 2003; Kakani, Saha \& Reddy, 2001; Stimpert \& Laux, 2011). This study measured firm size by the natural logarithm of Total Asset.

$$
\text { SIZE }=\operatorname{Ln}(\text { Total Asset })
$$

Capital Intensity/Asset Tangibility. Capital intensity measures the level of investment in non-current asset. In line with Pandey (2005) Asset tangibility is calculated as

$$
\text { ASTAN }=\frac{\text { Total Fixed Asset }}{\text { Total Asset }}
$$

All the study variables were normalized by log transformation using natural logarithm.

\subsection{Data analysis procedure}

The data obtained were analyzed using descriptive statistics and panel cointegration regression analysis. The descriptive statistics helped to portray the properties of the underlying variables. In order to establish whether long run relationship exists among the study variables, panel cointegration techniques namely Kao (1999) and Pedroni (1999, 2004) residual based cointegration approaches were applied. For the estimation of the long run elasticity coefficient, we employed panel fully modified ordinary least square under the frameworks of Grouped Mean FMOLS and Pooled FMOLS by Pedroni (2000, 2001) and Philips \& Moon (1999) respectively. Further diagnostic tests were also conducted such as coefficient and residual diagnostics under Variance of Inflation Factors (VIF) and Normality of the residuals.

\subsection{Empirical model}

To ascertain the effects working capital policies have on value creation, the following specified econometric model was adopted and modified from Pandey (2005).

$$
\begin{gathered}
L M / B_{i t}=\alpha_{i}+\beta_{1} L T C A / T A_{i t}+\beta_{2} L T C L / T A_{i t}+\beta_{3} L L E V_{i t}+ \\
\beta_{4} L S I Z E_{i t}+\beta_{5} L A S T A N_{i t}+\varepsilon_{i t}
\end{gathered}
$$

Where: $L M / B$ is the natural $\log$ of market-to-book ratio for firm $i$ in period $t$;

LTCA/TA - natural log of Total current asset to total asset ratio;

$L T C L / T A$ - natural log of Total of current liabilities to total asset ratio;

$L L E V$ - natural log of Financial leverage of firms measured as total debt to total capital; 


\section{LSIZE - Natural log of total asset;}

LASTAN - natural log of capital intensity measured as $F A / T A$;

$\alpha_{i}$ - individual specific intercept;

$\beta_{1}-\beta_{5}-$ are the estimated parameters;

$\varepsilon \quad$ - error term;

$i t$ - firm $i$ at time $t$.

\subsection{Panel units root test}

In conventional time series, various unit root tests have been proposed such as Augmented Dickey-Fuller test (ADF) and Philip-Perron (PP) test. However in panel setting, testing for unit root is recent. These tests include common unit root processes such as Breitung (2000), Hadri (2000), and Levin, Lin, \& Chu (2002) and those that allow for individual specific effect such as Im, Pesaran, \& Shin (2003), Maddala \& Wu (1999), and Choi (2001).

The study applied four panel unit root tests consisting of Levin, Lin, \& Chu (2002), Im, Pesaran, \& Shin (2003) and Fisher-type test using ADF by Maddala \& Wu (1999) and Hadri (2000). It must be noted that LLC, IPS and ADF all test the null hypothesis that the series contain unit root whereas Hadri test has null hypothesis of stationarity.

\subsection{Panel cointegration test}

When the panel data exhibit nonstationarity, it is possible to test whether there is a cointegrating relationship existing between them in the long-run. That is whether there is long-run association between the variables. In order to test for possible cointegration, the study used Pedroni (1999, 2004) and Kao (1999) panel residual cointegrating techniques and are briefly discussed here.

Following Pedroni (1999), the study considers the following fixed-effect model:

$$
\begin{gathered}
y_{i t}=\alpha_{i}+\beta_{1} L T C A / T A_{i t}+\beta_{2} L T C L / T A_{i t}+\beta_{3} L L E V_{i t}+\beta_{4} L S I Z E_{i t}+ \\
\beta_{5} L A S T A N_{i t}+\beta_{6} D 2007+\varepsilon_{i t}
\end{gathered}
$$

where $i=1,2, \ldots, N$ for each firm; $t=1,2, \ldots$, T observations over time; $\alpha_{\mathrm{i}}$ represents the individual-specific (fixed) effect intercept that is allowed to vary across individual firms and $\beta_{1}$ i, $\beta_{2}, \ldots, \beta_{5}$ are the slope coefficients which are also permitted to vary across individual firms; $y_{i t}$ represents the dependent variable, Market-to-Book ratio and $e_{i t}=$ $\rho_{i} e_{i t-1}+\varepsilon_{i t}$. D2007 is a common time dummy representing 1 if the year is 2007, otherwise zero.

The inclusion of a common time dummy, according to Pedroni (2001), is intended to capture the issue of shocks from the system and also deal with potential problem of shortrun cross-sectional dependency. The year 2007 saw the Ghanaian currency undergoing a 
redenomination exercise as well as the adoption of International Financial Reporting Standards (IFRSs) by Ghanaian listed firms for the first time and also marked the beginning of the global financial meltdown.

Pedroni $(1999,2004)$ developed seven panel cointegration test statistics to determine the existence of cointegration. Four within-dimension test statistics which assume homogeneity of the AR term and three group between-dimension test statistics which allow for heterogeneity of the AR term to test the null of no cointegration against the alternative hypothesis of cointegration. The first panel cointegration statistic (panel $v$ statistic) is similar to the long-run non-parametric variance ratio statistic for time series. The second statistic (Panel $\rho$ statistic) is analogous to Phillips \& Peron (1988) semiparametric 'rho' statistic while the third statistic (panel PP) and fourth statistic (panel ADF) are analogous to Phillips-Peron non-parametric t-statistic and the ADF t-statistic respectively. The other three panel cointegration statistics are based on a group mean. The within-dimension statistics are based on the estimators that effectively pooled the autoregressive coefficient across different members for the unit root test on the estimated residuals while the between-dimension simply average the individually estimated for each cross section $i$. However, these tests are only valid when all the variables are $\mathrm{I}(1)$. according to Wagner \& Hlouskova (2009) when the time series dimension is small, the $\mathrm{ADF}$ t-statistic based on the panel statistics are the best to test for the cointegration. Since the study sample was small, the ADF $t$-statistics was relied on to decide possible cointegration. One disadvantage of Pedroni's residual cointegration is that it cannot be applied when variables are more than seven. As a confirmation, Kao, 1999 panel residual cointegration was also applied.

\subsection{Estimating long-run effect}

In order to determine the effect aggressive/conservative working capital policies have on value creation after evidence of long run relationship is established, the study used recently developed Fully-Modified Ordinary Least Square (FMOLS). This estimator is robust to serial correlation and heterogeneity and hence preferable to simple OLS estimation. Pedroni $(2000,2001)$ proposes a grouped FMOLS estimator which averages over the individual cross section FMOLS estimates. One of the merits of using betweendimension estimators as opposed to within-dimension is that the mode in which the data is pooled allows for greater flexibility in the presence of heterogeneity of the cointegrating vectors. Pedroni $(2000,2001)$ argues that the grouped mean test statistics are found to do extremely well in small samples provided the time series dimension is not smaller than the cross sectional dimension. The point estimate for the between dimension estimator can be interpreted as the mean value of the cointegrating vectors (Pedroni, 2000). Consider the following regression:

$$
\begin{aligned}
& L M / B_{i t}=\alpha_{i}+\beta_{1 i} L T C A / T A_{i t}+\beta_{2 i} L T C L / T A_{i t}+\beta_{3 i} L L E V_{i t}+ \\
& \beta_{4 i} L_{S I Z E_{i t}}+\beta_{5 i} L_{A S T A N}+\beta_{6 i} D 2007+\varepsilon_{i t}
\end{aligned}
$$

Where $L M / B$ is the dependent variable and $L T C A / T A, L T C L / L T A, L L E V, L S I Z E$, and $L A S T A N$ are cointegrating regressors with slopes $\beta_{1 i}, \beta_{2 i}, \beta_{3 i}, \beta_{4 i}$ and $\beta_{5 i}$ which may or may not be homogeneous across $i$; D2007 is a common time dummy variable to capture 
shock from the system; $\alpha_{i}$ denotes individual specific effect and $\varepsilon_{i t}$ is the disturbance term. The expression for the between-dimension group-mean panel FMOLS estimator as outlined in Pedroni (2001) is given as:

$$
\hat{\beta}_{G F M}^{*}=\frac{1}{N} \sum_{i=1}^{N} \hat{\beta}_{F M, i}^{*}
$$

Where $\hat{\beta}_{F M, i}$ is the time series FMOLS estimator which is applied to each firm-member. The associated t-statistic for the between-dimension estimator is given as:

$$
t \hat{\beta}_{G F M}^{*}=\frac{1}{N} \sqrt{N} \sum_{i=1}^{N} t \hat{B}_{F M, i}^{*}
$$

Where $t \hat{\beta}_{F M i}^{*}$ is the associated t value from the individual FMOLS estimators.

Erdem, Ucler, \& Bulul (2014) (as cited in Demirgunes, 2015) opine that panel fully modified ordinary least squares estimator is appropriate if all the cointegrating variables are integrated of order 1, i.e. I (1).

Thus, the empirical models are specified as

$$
\begin{gathered}
L M / B_{i t}=\alpha_{i}+\beta_{1} L T C A / T A_{i t}+\beta_{2} L T C L / T A_{i t}+\beta_{3} L L E V_{i t}+ \\
\beta_{4} L S I Z E_{i t}+\beta_{5} L A S T A N_{i t}+\beta_{6} D 2007+\varepsilon_{i t}
\end{gathered}
$$

The variables are as already defined. The basic model was also estimated using standard pooled FMOLS by Philips \& Moon (1999).

\section{Empirical results and discussion}

\subsection{Descriptive statistics}

TABLE 1. DESCRIPTIVE STATISTICS OF THE STUDY VARIABLES

\begin{tabular}{lcccccccc}
\hline VARIABLE & OBs. & MeAN & MediAN & Std. DEV & MiN & MAX & J-B StATISTIC & P-VALUE \\
\hline M/BR & 120 & 4.367 & 2.615 & 5.913 & 0.076 & 35.07 & 779.35 & .0000 \\
\hline TCA/TA & 120 & 0.5412 & 0.5562 & 0.188 & 0.165 & 0.946 & 2.211 & .3310 \\
\hline TCL/TA & 120 & 0.4816 & 0.4323 & 0.186 & 0.1646 & 0.8943 & 6.400 & .0407 \\
\hline LEV & 120 & 0.5838 & .5657 & 0.191 & 0.1048 & 0.9579 & 3.286 & .1933 \\
\hline SIZE & 120 & 17.55 & 17.83 & 1.516 & 13.90 & 19.99 & 7.520 & .0231 \\
\hline ASTAN & 120 & 0.4588 & 0.4438 & 0.188 & 0.055 & 0.8353 & 2.210 & .3310 \\
\hline
\end{tabular}

Source: Field work, 2017. 
Table I presents the descriptive statistics of the study variables. As can be observed, the median market-to-book ratio is 2.615 (Mean value 4.367; SD 5.913) for all the companies. The average market-to-book ratio for all the selected companies was above 1 . This means that the market value of the companies exceeds the book value of the equity by $162 \%$ during the study period.

The average value of investment policy measured by TCA/TA for all the selected firm was $54.12 \%(\mathrm{SD}=18.8 \%)$ as depicted on Table I. Thus, the study firms during the period pursued relatively conservative policies in managing their current assets resources. Again, from Table I, the mean financing policy proxy by TCL/TA for all the firms was $48.16 \%$ $(\mathrm{SD}=18.6 \%)$. Financial leverage registered a mean of $58 \%(\mathrm{SD}=19 \%)$ for all the firms implying that these firms rely more on debts than equity as a source of finance. An average value of 17.55 was recorded by firm size as shown on Table I. Capital intensity depicted as ASTAN was on average about $46 \%$ during the period under review.

\subsection{Panel unit root test}

TABLE 2. PANel unit ROOT TeStS In LeVELS

\begin{tabular}{|c|c|c|c|c|}
\hline VARIABLE & LLC & IPS & ADF & HADRI \\
\hline$L M / B$ & -1.4914 & -0.5764 & 24.188 & $4.8487^{* *}$ \\
\hline LTCA_TA & $-1.8278^{*}$ & -0.1533 & 19.087 & $3.7324^{* *}$ \\
\hline LTCL_TA & -1.3921 & -0.7639 & 24.346 & $2.6241^{* *}$ \\
\hline LLEV & -1.5590 & -1.1241 & 31.112 & $2.0647^{*}$ \\
\hline LSIZE & -0.4511 & 2.3618 & 10.338 & $8.6390^{* *}$ \\
\hline LASTAN & -0.8144 & 0.3011 & 18.688 & $3.6927^{* *}$ \\
\hline $\begin{array}{l}\text { Note: }{ }^{*},{ }^{* *} \text { - i } \\
\text { Pesaran, \& } \\
\text { Probabilities } \\
\text { asymptotic n }\end{array}$ & $\begin{array}{l}\text { cant level } 0 \\
\text { F - Fisher t } \\
\text { are comput }\end{array}$ & $\begin{array}{l}\text { \% respecti } \\
\text { uare by } \mathrm{Ma} \\
\text { n asymptoti }\end{array}$ & $\begin{array}{l}\text { Levin, Lin, } \\
\text { (1999); H } \\
\text { e distribut }\end{array}$ & $\begin{array}{l}\text { 2), IPS - Im, } \\
\text { (2000). } \\
\text { tests assume }\end{array}$ \\
\hline
\end{tabular}

TABLE 3. PANEL UNIT ROOT TESTS IN FIRST DIFFERENCE

\begin{tabular}{|c|c|c|c|c|}
\hline VARIABLE & LLC & IPS & ADF & HADRI \\
\hline$\Delta L M / B$ & $-8.5225^{\star *}$ & $-6.7754^{* *}$ & $75.962^{* *}$ & 1.1007 \\
\hline$\triangle L T C A \_T A$ & $-7.9058^{* *}$ & $-5.3366^{* *}$ & $63.606^{* *}$ & 0.1882 \\
\hline$\triangle L T C L \_T A$ & $-9.6643^{\star *}$ & $-6.9121^{\star \star}$ & $78.398^{\star \star}$ & 0.7008 \\
\hline$\triangle L L E V$ & $-8.5849^{* *}$ & $-6.0297^{* *}$ & $70.594^{* *}$ & 1.1776 \\
\hline$\triangle L S I Z E$ & $-6.4100^{* *}$ & $-4.7319^{* \star}$ & $57.801^{\text {** }}$ & -0.1166 \\
\hline$\triangle L A S T A N$ & $-5.7864^{* *}$ & $-4.6492^{* *}$ & $57.498^{* *}$ & $3.5724^{* *}$ \\
\hline \multicolumn{5}{|c|}{$\begin{array}{l}\text { Note: }{ }^{*},{ }^{* *} \text { indicate a significant level of } 5 \% \text { and } 1 \% \text { respectively. LLC - Levin, Lin, \& Chu (2002), IPS - Im, } \\
\text { Pesaran, \& Shin (2003), ADF - Fisher type Chi square by Maddala \& Wu (1999); Hadri - Hadri (2000). } \\
\text { Probabilities for fisher tests are computed using an asymptotic Chi-square distribution. All other tests assume } \\
\text { asymptotic normality. }\end{array}$} \\
\hline
\end{tabular}


The summary results from the panel unit root tests are presented on Table II and Table III. Table II depicts the results on level data of the study variables whereas Table III shows the results at the first differences. From Table II it could be observed that LLC, IPS and ADF tests all failed to reject the null hypotheses for all the variables at $5 \%$ level of significance with the exception of $\log$ of TCA_TA in the level form. However, Hadri test rejected the null hypothesis for all the variables in the levels as the P. Values were all significant at 5 percent level of significance.

However, it can be observed from Table III that LLC, IPS and ADF tests failed to accept the null hypothesis of a unit root in the difference form. Additionally, the Hadri test also failed to reject the null of stationarity in the difference form for all the variables except log of capital intensity. The findings indicate that the variables are I(1). Hence, applying Ordinary Least Squares or Generalized Least Square on them directly will result in biased and spurious estimates.

\subsection{Results from the tests of cointegration}

The residual based cointegration tests in the panel setting developed recently by Pedroni (1999, 2004) and Kao (1999) were utilized to ascertain if there exists a stable long run association between variables of working capital and value creation variable. The outcome from the tests is presented in Tables IV for Pedroni residual based and Table $\mathrm{V}$ for Kao residual based cointegration methods respectively. It must be observed from equation (2) that these models included common time dummy. From Table IV, both the panel ADF and panel PP statistics were all strongly significant at 1\% level. Again, the Group ADF and Group PP statistics were significant at 1\% significance level. This empirical evidence firmly suggests that there is a strong stable long-run association between the study variables. Thus, there is a long-run association between working capital management and shareholder value creation as proxy by market-to-book ratio. This evidence validates the findings by Akinlo (2011), Awad \& Jayyar (2013) as well as Adam et al. (2017) who found long run relationship between working capital management variables and profitability.

TABle 4. PEDRoni RESIDUAL COINTEGRATION TESTS: DePENDENT VARIABLE - M/B RATIO

\begin{tabular}{|c|c|c|c|c|}
\hline \multicolumn{5}{|c|}{ ALTERNATIVE HYPOTHESIS: COMMON AR COEFS. (WITHIN-DIMENSION) } \\
\hline & Statistics & P. Value & Weighted statistics & P. Value \\
\hline Panel v-Statistic & -0.7950 & .7867 & -1.9383 & .9737 \\
\hline Panel rho-Statistic & 2.2754 & .9886 & 2.5900 & .9952 \\
\hline Panel PP-Statistic & -7.4188 & $.0000^{\star \star \star}$ & -8.2243 & $.0000^{\star \star \star}$ \\
\hline Panel ADF-Statistic & -6.7638 & $.0000^{* * *}$ & -6.5695 & $.0000^{* * *}$ \\
\hline \multicolumn{5}{|c|}{ ALTERNATIVE HYPOTHESIS: COMMON AR COEFS. (BETWEEN-DIMENSION) } \\
\hline & Statistics & Prob. & & \\
\hline Group rho- Statistic & 3.9323 & 1.0000 & & \\
\hline Group PP- Statistic & -10.6232 & $.0000^{\star \star \star}$ & & \\
\hline Group ADF- Statistic & -6.3780 & $.0000^{\star * \star}$ & & \\
\hline
\end{tabular}

The result from Table $\mathrm{V}$ also revealed that Kao's ADF statistics was significant at 5\% level confirming the Pedroni's cointegration result in Table IV. This findings, clearly suggests 
that there exist a strong long-run association between value creation proxy by $\mathrm{M} / \mathrm{B}$ ratio and working capital management variables. Thus, in the long-run these policies have a bearing with the value creation.

TABLE 5. KAO RESIDUAL COINTEGRATION TESTS: DEPENDENT VARIABLE - M/B RATIO

\begin{tabular}{lcc}
\hline & t-Statistic & Prob. \\
\hline ADF & -1.6946 & $0.0451^{* *}$ \\
\hline Residual variance & 0.2141 & \\
\hline HAC variance & 0.1808 & \\
\hline $\begin{array}{l}\text { Note: }{ }^{* *} \text { indicates the null hypothesis is rejected at } \\
\text { selection was based on SIC at maximum lag of } 2 .\end{array}$
\end{tabular}

\subsection{Cointegration regression results}

After establishing that there exist a stable long term association among the variables, next panel cointegration regression techniques specifically grouped mean FMOLS by Pedroni (2000, 2001) and standard pooled FMOLS by Philips \& Moon (1999) were adopted to ascertain the direction of the association among the cointegrating variables and establish the effect working capital management policies have on value creation. Table VI presents the results from the two FMOLS methods involving dependent variable $\mathrm{M} / \mathrm{B}$ ratio and cointegrating repressor variables. From Table VI, when common time dummy is controlled for, the current asset investment policy proxy by TCA/TA revealed mixed results depending on the estimation method. Whereas the group means estimated method indicated that TCA/TA ratio has negative effect on value creation, the pooled estimation indicated that TCA/TA has positive effect on value creation. However, only group mean estimation coefficient was significant at $10 \%$ level of significant. When time dummy is not considered in the estimation, the coefficient for current asset investment policy tends to be significant at the conventional level of $5 \%$ for group mean as reported in Table VIII in the appendix.

The negative coefficient as revealed by the group mean suggests a positive association between the relative degree of aggressiveness of current asset investment and value creation. On the other hand, the positive coefficient as reported by the pooled estimation suggests negative association between the relative degree of aggressive investment policy and MBR. These mixed results may mean that firms would be better off in creating value for shareholders by pursuing relatively moderate policies concerning current asset investment. The negative relationship found between TCA/TA ratio and MBR indicates that as firms increase investment in current asset, it has the effect of reducing the shareholders' value. This evidence supports the theory that excessive current asset investment leads to low profitability and consequently shareholder value (Pandey, 2010; Van Horne \& Wachowicz, 2009) and also confirms Bandara \& Werekoon (2014) who found that firms pursuing moderate policies create value measured by Economic value added and Market value added.

The results from study again indicated current asset financing policies have negative relationship with MBR as indicated by both group mean and pooled estimations whether time dummy is considered or not. The negative coefficient also indicated positive association between relative degree of conservative current asset financing policy and 
MBR. Thus the firms that are seen to finance their operations with more long term capital are rewarded in the long run. These findings contradict the long held notion that aggressive current liability management enhances firms' value (Weinraub \& Visscher, 1998).

\section{TABLE 6. FMOLS RESULTS: DEPENDENT VARIABLE - LMBR.}

\begin{tabular}{|c|c|c|c|c|c|c|c|c|}
\hline \multirow[t]{2}{*}{ VARIABLE } & \multicolumn{4}{|c|}{ GROUPED MEAN ESTIMATION } & \multicolumn{4}{|c|}{ POOLED ESTIMATION } \\
\hline & Coeff. & Std. Er & t-stat & p. value & Coeff & Std Er & t-stat & p. value \\
\hline LTCA_TA & -1.721 & 1.008 & -1.707 & $.0911^{*}$ & 0.8507 & 0.5217 & 1.631 & .1063 \\
\hline LTCL_TA & -1.519 & 0.513 & -2.962 & $.0039^{* * *}$ & -0.6876 & 0.3591 & -1.915 & $.0586^{*}$ \\
\hline LLEV & 3.059 & 0.589 & 5.186 & $.0000^{\star * *}$ & 1.8031 & 0.4469 & 4.034 & $.0001^{* \star \star}$ \\
\hline LSIZE & -0.590 & 0.228 & -2.586 & $.0112^{\star *}$ & -0.4345 & 0.1067 & -4.068 & $.0001^{\star \star \star}$ \\
\hline LASTAN & -2.175 & 1.160 & -1.874 & $.0640^{*}$ & -0.6497 & 0.3991 & -1.628 & .1069 \\
\hline D2007 & 0.110 & 0.091 & 1.203 & .2316 & 0.0893 & 0.2455 & 0.364 & .7168 \\
\hline
\end{tabular}

Thus, firms would increase shareholder value by adopting aggressive approach in the management of total current asset resources. However, shareholder value can be created in the long run if firms adopt conservative approach towards managing current asset financing. This means investors penalized companies with aggressive current assets financing policies in the long run. The study also revealed that financial leverage has positive and statistical significant effect on the shareholder value creation. Asset tangibility was found to be negative and insignificant effect on market to book ratio at the conventional level when time dummy was considered. These findings agree with Pandey (2005) who also found insignificant relationship between asset tangibility and market to book ratio. However, size as measured by the natural log of total asset revealed a significant negative relationship with market to book ratio. Thus, in the long run the size of the firm is inversely related to the value creation. The finding agree Korankye (2013) and Kumar (2015) who found negative significant relationship with firm size and market to book ratio.

The inclusion of a common time dummy in the estimation does not alter the direction of the results generally. The dummy variable D2007 indicating 1 for the year 2007 and 0 otherwise, was found to have a positive and insignificant effect on MBR. Ghana adopted IFRS in January, 2007 for all publicly traded entities and undertook a currency redenomination in the same year. It seems that these two accounting and economic restructuring have impacted positively on MBR albeit their insignificant.

\subsection{Diagnostics checks}

Table VII and Table IX (see the appendix for Table IX) present the coefficients and residual diagnostics checks for both grouped estimation and pooled estimation. As can be seen from Table VII and Table IX there is no multicollinearity problem in the regression models as the variance inflation factors (VIF) are all within the acceptable range. Also, the Jarque-Bera statistic for the test of normality of residuals indicated that the null of normality of residuals cannot be rejected as the p. values far exceed the alpha level of $5 \%$ 
whether common time dummy was included or not. Thus the regression estimates from both methods can be relied upon.

\section{TABLE 7. COEFFICIENT AND RESIDUAL DIAGNOSTICS}

\begin{tabular}{|c|c|c|c|c|}
\hline \multirow[t]{3}{*}{ VARIABLE } & \multicolumn{2}{|c|}{ GROUPED ESTIMATION } & \multicolumn{2}{|c|}{ POOLED ESTIMATION } \\
\hline & \multicolumn{4}{|c|}{ VARIANCE INFLATION FACTORS } \\
\hline & $\begin{array}{l}\text { Coefficient } \\
\text { Variance }\end{array}$ & Uncentered VIF & $\begin{array}{l}\text { Coefficient } \\
\text { Variance }\end{array}$ & Uncentered VIF \\
\hline LTCA_TA & 1.017140 & 3.854787 & 0.272219 & 3.645721 \\
\hline LTCL_TA & 0.262908 & 5.936670 & 0.128986 & 2.433991 \\
\hline LLEV & 0.348001 & 6.082526 & 0.199794 & 2.035245 \\
\hline LSIZE & 0.052157 & 1.367112 & 0.011406 & 1.094670 \\
\hline LASTAN & 1.346973 & 3.744138 & 0.159287 & 3.178902 \\
\hline D2007 & 0.008350 & 1.184776 & 0.060271 & 1.145593 \\
\hline \multicolumn{5}{|c|}{ TEST OF NORMALITY OF RESIDUALS } \\
\hline & $\begin{array}{c}\text { Jarque-Bera } \\
\text { Statistics }\end{array}$ & P. Value & $\begin{array}{c}\text { Jarque-Bera } \\
\text { Statistics }\end{array}$ & P. Value \\
\hline & .5291 & .7675 & 0.3302 & .8478 \\
\hline
\end{tabular}

\section{Conclusion}

Working capital management is seen as a key factor for creating shareholder value. Since efficient and effective management of working capital leads to increase profitability, it has positive effects on shareholder value creation. However, few empirical works have been undertaken to investigate the effects working capital management have on value creation. This study sought to determine the effects of aggressive/ conservative working capital policies on value creation using listed non-financial companies on the GSE over the period 2004-2015. The study adopted quantitative research design applied to panel cointegration and panel fully modified ordinary least square methodology. Both Kao (1999) and Pedroni (1999, 2004) residual based panel cointegration results indicated that there was an equilibrium association existing among working capital management variables and shareholders' value creation. The results from the grouped FMOLS revealed that in the long term aggressive current asset investment policies enhance market-to-book ratio. However, conservative financing policies with regard to current asset enhance market-tobook ratio in the long-run. The study also found firm size and asset tangibility have negative association with market -to- book ratio. However, debt-equity ratio was found to impact positively on the shareholders' value creation during the period under consideration. Hence, it is recommended that listed firms in Ghana should manage efficiently and effectively the short-term resources and finances. 


\section{References}

Adam, M. A., Quansah, E., \& Kawor, S. (2017). Working capital management policies and returns of listed manufacturing firms in Ghana. Scientific annals of economics and business, 64(2), 255269. doi: 10.1515/saeb-2017-0017.

Akinlo, O. (2011). Does working capital cause profitability? The Nigerian experience. Journal of Modern Accounting and Auditing, 7(5), 457-462.

Ankudinov, A., \& Lebedev, O. (2014). Investment drivers of shareholder value creation in large publicly traded Russian companies. Investment Management and Financial Innovations, 11 (2), $77-$ 85.

Atiyet, B. A. (2012). The impact of financing decision on the shareholder value creation. Journal of Business Studies Quarterly, 4(1), 44-63.

Awad, I., \& Jayyar, F. (2013). Working capital management, liquidity and profitability of the manufacturing sector in Palestine: Panel co-integration and causality. Modern Economy, 4, 662-671.

Bammeri, O., \& Dehani, N. (2013). The effect of capital management on stock returns of accepted companies in Tehran Stock Exchange. European Online Journal of Natural and Social Sciences, 2(3), 1061-1069

Bandara, R. M. S. (2015). Impact of working capital management policy on market value addition. Global Journal of Contemporary Research in Accounting, Auditing and Business Ethics, 1(2), 354-373.

Bandara, R. M S., \& Weeraboon, Y. K. B (2014). Impact of working capital management practices on a firm value. Retrieved Julay 17, 2018, from http://www.kln.ac.lk/uokr/ ICBI2011/AandF\%20140.pdf

Baños-Caballero, S., García-Teruel, P. J., \& Martínez-Solano, P. (2014). Working capital management, corporate performance, and financial constraints. Journal of Business Research, 67(3), 332-338. doi:101016/j.jbusres.2013.01.016

Black, A., Wright, P., Bachman, P. E., \& Davies, J. (1998). In search of shareholder value: managing the drivers of performance (2nd ed.). London, England: Prentice Hall.

Deloof, M. (2003). Does working capital management affect profitability of Belgian firms? Journal of Business, Finance and Accounting, 30, 573-587.

Demirgunes, K. (2015). Determinants of target dividend payout ratio: A panel ARDL. International Journal of Economics and Financial Issues, 5(2), 418-426.

Duggal, R., \& Budden, M. C. (2015). Further evidence of the creation of value through the management of net working capital: An analysis of S\&P 500 firms. Journal of Business \& Economics Research - First Quarter, 13(1), 79-82.

Ernst and Young (2016). All tied up, working capital management report, 2016. Retrieved July 22, 2018, from http://www.ey.com

Gross, S. (2006). Banks and shareholder value: An overview of bank valuation and empirical evidence on shareholder value for banks (1. Aufl.). Wiesbaden: Dt. Univ.-Verlag.

Im, K. S., Pesaran, M. H., \& Shin, Y. (2003). Testing for Unit Roots in Heterogeneous Panels. Journal of Econometrics, 115, 53-74.

Korankye, T. (2013). Determinants of Shareholder Value Creation of Listed Banks in Ghana. International Journal of Empirical Finance, 1(1), 7-12. Available at http://rassweb.com 
Kumar, R. B. (2015). Determinants of value creation: An empirical examination from UAE market. International Journal of Economics and Financial Issues, 5(1), 75-85.

Levin, A., Lin, C. F., \& Chu, C. (2002). Unit root tests in panel data: Asymptotic and finite-sample properties. Journal of Econometrics, 108(1), 1-24.

Maddala, G. S., \& Wu, S. (1999). A comparative study of unit root tests with panel data and a new simple test. Oxford Bulletin of Economics and Statistics, 61, 631-52.

Mohamad, N. A. B., \& Saad, N. B. M. (2010). Working capital management: The effect of market valuation and profitability in Malaysia. International Journal of Business and Management, 5(11), 140-147.

Narang, S., \& Kaur, M. (2014). Impact of firm-specific attributes on shareholder value creation of Indian companies: An empirical analysis. Global Business Review, 15(4), 847-866.

Nazir, M. S., \& Afza, T (2009). Impact of aggressive working capital management policy on firms' profitability. The IUP Journal of Applied Finance, 15(8), 19-31.

Oseifuah, E. K., \& Gyekye, A. (2017). Working capital management and shareholders' wealth creation: evidence from nonfinancial firms. Investment Management and Financial Innovations, 14(1), 80-88. doi:10.21511/imfi14(1).2017.08

Pandey, I. M. (2005). What drives shareholder value? (Working paper WP, No 2005-09-04). Ahmedabab, India: Indian Institute of Management.

Pandey, I.M. (2010), Financial Management (10 th ed.). New Delhi, India: Vikas Publishers.

Pedroni, P. (1999). Critical values for cointegration tests in heterogeneous panels with multiple regressors. Oxford Bulletin of Economics and Statistics, 61, 653-670.

Pedroni, P. (2000). Fully modified OLS for heterogeneous cointegrated panels. Nonstationary Panels, Panel Cointegration and Dynamic Panels, 15, 93-138.

Pedroni, P. (2001). Purchasing power parity tests in cointegrated panels. Review of Economics and Statistics, 83, 727-731.

Pedroni, P. (2004). Panel cointegration: Asymptotic and finite sample properties of pooled time series tests with an application to the PPP hypothesis. Econometric Theory, 20, 597-625.

Rappaport, A. (1986). Creating Shareholder V alue: The new standard for business performance. New York, NY: The Free Press.

Shin, H. H., \& Soenen, L. (1998). Efficiency of working capital and corporate profitability. Financial Practice and Education, 8, 37-45.

Smith, K. (1980). Profitability versus liquidity tradeoffs in working capital management. In readings on the management of working capital, St Paul, MN: West Publishing Company, 549-562

Van Horne, J. C., \& Wachowicz, J. M. (2009). Fundamentals of Financial Management (13 ${ }^{\text {th }}$ ed.). Harlow, England: Pearson Education.

Wagner, M., \& Hlouskova, J. (2009). The performance of panel cointegration methods: Results from a large scale simulation study. Econometric Reviews, 29(2), 182-223.

Wasiuzzaman, S. (2015) Working capital and firm value in an emerging market. International Journal of Managerial Finance, 11(1), 60-79, https://doi.org/10.1108/IJMF-01-2013-0016

Watson, D., \& Head, A. (2007). Corporate finance: Principles and practice (4th ed.). Harlow, England: Prentice Hall.

Weinraub, H. J., \& Visscher, S. (1998). Industry practice relating to aggressive conservative working capital policies. Journal of Financial and Strategic Decision, 11(2), 11-18 


\section{Appendix}

TABLE 8. FMOLS RESULTS: DEPENDENT VARIABLE - LMBR

\begin{tabular}{lcccccc}
\hline \multirow{2}{*}{ VARIABLE } & \multicolumn{3}{c}{ GROUPED MEAN ESTIMATION } & \multicolumn{3}{c}{ POOLED ESTIMATION } \\
\cline { 2 - 7 } & Coeff. & t-stat & p. value & Coeff & t-stat & p. value \\
\hline LTCA_TA & -2.225 & -2.139 & $.0349^{* *}$ & 0.871 & 1.688 & $.0946^{*}$ \\
\hline LTCL_TA & -1.291 & -3.000 & $.0034^{* * *}$ & -0.719 & -2.066 & $.0415^{* *}$ \\
\hline LLEV & 3.054 & 5.959 & $.0000^{* * *}$ & 1.825 & 4.131 & $.0001^{* * *}$ \\
\hline LSIZE & -0.656 & -2.953 & $.0040^{* * *}$ & -0.451 & -4.357 & $.0000^{* * *}$ \\
\hline LASTAN & -2.723 & -2.124 & $.0362^{* *}$ & -0.647 & -1.632 & .1060 \\
\hline
\end{tabular}

TABLE 9. COEFFICIENT AND RESIDUAL DIAGNOSTICS

\begin{tabular}{lcc}
\hline \multirow{2}{*}{ VARIABLE } & GROUPED MEAN ESTIMATION & PoOLED ESTIMATION \\
\cline { 2 - 3 } & \multicolumn{2}{c}{ Variance Inflation Factors } \\
\cline { 2 - 3 } & VIF & VIF \\
\hline LTCA_TA & 3.752099 & 3.558522 \\
\hline LTCL_TA & 4.636249 & 2.283126 \\
\hline LLEV & 4.721365 & 1.984604 \\
\hline LSIZE & 1.322637 & 1.030058 \\
\hline LASTAN & 3.622094 & 3.138113 \\
\hline \multicolumn{3}{c}{ Test of Normality of residuals } \\
\hline Jarque-Bera & 2.348 & 0.3638 \\
\hline P. Value & .3090 & .8254 \\
\hline
\end{tabular}

TABLE A. FIRMS INCLUDED IN THE STUDY

\begin{tabular}{llc}
\hline No. & \multicolumn{1}{c}{ FIRM } & GSE CLASSIFICATION \\
\hline 1 & Aluworks Ltd & Manufacturing \\
\hline 2 & Camelot Gh. Ltd & Manufacturing \\
\hline 3 & Fan Milk Gh. Ltd & Food \& Beverages \\
\hline 4 & Guinness Gh. Breweries Ltd & Food \& Beverages \\
\hline 5 & PZ Cussons Gh. Ltd & Manufacturing \\
\hline 6 & Unilever Gh. Ltd & Manufacturing \\
\hline 7 & Starwin Products Ltd & Manufacturing \\
\hline 8 & Mechanical Lyodd Ltd & Distribution \\
\hline 9 & Produce Buying Company Ltd & Distribution \\
\hline 10 & Total Petroleum Ghana Ltd & Distribution \\
\hline \multicolumn{2}{l}{ Source: Researchers' construct. }
\end{tabular}

